\title{
Structural and functional profile of livestock markets in India
}

\section{Vishnu Dev R. S. ${ }^{\text {a }}$ and (iD S. Harikumar}

${ }^{\mathrm{a}}$ Research Scholar, Department of Livestock Production Management, College of Veterinary and Animal Sciences, Mannuthy - 680651.

${ }^{\mathrm{b}}$ Assistant Professor, Department of Livestock Production Management, College of Veterinary and Animal Sciences, Mannuthy, Thrissur - 680651.

Corresponding author: Vishnu Dev R.S. | email: drvishnudevrs@gmail.com

Co-author: VKV:harikumar@kvasu.ac.in

Received: 06-11-2020, Accepted: 23-11-2020, Published online: 21-12-2020

\begin{abstract}
Livestock markets perform major exchange function of animals in India. These markets play a considerable share in the economic gain of farmers and act as a social and cultural migration hub for the domestic and foreign tourists also. But they are largely unorganized and dominated by informal traders. The structural base of livestock markets determines the sales pattern and the major price value of animals is bagged by middlemen. These markets are functioning under the jurisdiction of the state governments and supervision is under the control of the local bodies. The different marketing strategies in the markets and pricing are affected by qualitative and quantitative factors of animals. The major constraints regarding the livestock markets are the lack of facilities and unawareness of knowledge among the sellers and buyers. The role of livestock markets in disease transmission is also a matter of concern. Details regarding animal movement will facilitate epidemiological studies to prevent contagious diseases from outside the country. In the present COVID-19 pandemic, conventional livestock markets are closed and virtual markets based on online platforms such as Facebook, WhatsApp and E-commerce sites are coming up and these transformations are absolutely inevitable.
\end{abstract}

Keywords: $\quad$ Livestock markets, Marketing strategies, India

doi: https://doi.org/10.51128/jfas.2020.A016 | How to cite this article: Vishnu Dev R. S. and S. Harikumar. 2020. Structural and functional profile of livestock markets in India. Journal of Food and Animal Sciences, 01(02): 87-92.

Copyright: Vishnu Dev and Harikumar, 2020. Open Access. This article is distributed under the terms of the Creative Commons Attribution 4.0 International License (http://creativecommons.org/licenses/by/4.0/), which permits unrestricted use, distribution, and reproduction in any medium, provided you give appropriate credit to the original author(s) and the source, provide a link to the Creative Commons license, and indicate if changes were made. The Creative Commons Public Domain Dedication waiver (http://creativecommons.org/publicdomain/zero/1.0/) applies to the data made available in this article, unless otherwise stated. 


\section{Introduction}

Livestock markets are an integral part of India's agriculture and perform the exchange function of cattle and other domestic animals. Markets provide livelihood support to the rural population of India. The livestock markets in the villages are mainly confined among the villagers, vendors and local markets (Das and Tripathi, 2013). Hence, the code of conduct of marketing is regulated by the villagers and vendors depending on the local socio-economic and external market forces. The sector has been growing faster, yet markets for livestock and livestock products are remaining unorganised, traditional and fragmented even after decades of economic development.

Meena et al. (2017) reported that the cattle fairs provide a crucial platform to the farmers and traders for the transaction of live animals and but the arrivals and transactions of animals had declined year by year. The middlemen capture the major share of animal prices and several malpractices are adopted by the sellers to hide the physical defects of animals. Hence it badly affects the income of farmers and leads to destabilised conditions. Therefore, the function of livestock markets should be in a scientific manner and well-coordinated. During the COVID-19 period, livestock markets are forced to remain closed. The livestock markets change into an online platform like e-commerce sites, social media, etc. After the onset of the COVID-19 pandemic, farmers are considering the opportunities of technology in cattle marketing as. This review is targeted to collate and synthesize information about the structural and functional profile of livestock markets in India and to figure out the future possibilities of cattle markets, especially in the COVID-19 pandemic.

\section{Function of livestock markets}

According to Bharti et al. (2015), livestock markets are coming under the jurisdiction of the state governments and supervision is under the control of the local self-government. The patterns of cattle composition vary dramatically in cattle markets and the population of crossbred cattle mainly of females has increased faster in both the rural and urban areas due to high milk yield (Kumar et al., 2019). Small ruminant animal marketing is unorganized and the farmers are not in a sound position to hold the animals for a longer period to grab better prices (Senthilkumar et al.,
2012). The traders in the goat marketing network are regularly monitoring the goat farmers in the villages daily and collect the information of different types, age and availability of goats in Ajmer and Jaipur districts of Rajasthan (Kumar et al., 2010).

Cattle smuggling is more in the IndiaBangladesh border resulting in the loss of the Indian economy. According to Bhattacharjee (2013), the majority of the Indian states have banned cow slaughter which favours the traders to transport animals illegally across the border. The high demand for buffalo meat is increasing mainly due to the ban on cow slaughter in many states of India and also the traders collect buffaloes from the farmers directly or buy from livestock markets and sell to exporters (Nomani and Salman, 2016).

\section{Background of livestock markets}

Livestock fairs have been an integral part of Indian society since ancient times. Fairs or 'melas' are originated from our traditional customs, religion and belief. The socio-cultural life of rural areas is reflected in the animal fairs and attracts a large number of domestic and foreign tourists as well (Das et al., 2014). These fairs develop a wealth of opportunities for each state in India and a systematic approach to fairs brings in tourism revenue for the state (Munjal and Jauhari, 2015). There are many fairs conducted in different parts of India and some of the largest livestock fairs in India are the following.

The Sonepur Cattle Fair or 'Hariharnath Kshetra Mela,' touted to be the biggest cattle fair of Asia, takes place for a period of 15 days in November or December at the confluence of Ganga and Gandak Rivers in Bihar (Varma et al., 2010). Sonepur Mela is the only place where such a large number of elephants were traded. Nowadays elephants are brought to the fairs for display only, not for the sale. Many farm animals from all breeds of cattle, buffaloes, donkeys, ponies, horses, rabbits, goats and occasionally camels also are brought to Sonpur Mela. Another famous one is the Pushkar fair which starts with Kartik Shukla Ekadashi and continues for five days till Kartik Poornima in the month of October-November in Pushkar town in Rajasthan. This five-day fair is famous for the trading of camels and said to be the world's largest camel fair (Khan, 2017). The government of Rajasthan has taken an interest in conducting the animal fair, not only for 
tourist attraction but to organise and encouraging animal husbandry activities also (Singh, 2016). Nagaur cattle Fair is celebrated in the renowned town of Nagaur. It is an annual festival, which is located between Bikaner and Jodhpur in Rajasthan. In this fair, more than 75,000 camels, horses and bullocks are traded every year. Jhalawar Cattle Fair (Chandrabhaga Fair) is held on the bank of Chandrabhaga River in Jhalawar district of Rajasthan every year. On the last day of Kartik Poornima (October-November), Chandrabhaga Fair is celebrated. Another famous cattle fair in Rajasthan is Kolayat Cattle Fair. It is held in the Bikaner district and is also known as Kapil Muni fair. Kolayat fair is a major fair of Bikaner and largest cattle fair of district organized during the month of December. Buffaloes, horses, camels and other animals are also traded in this place. The Bateshwar Fair (Agra Cattle Fair) takes place in the town of Bateshwar near Agra on the banks of the holy river Yamuna in Uttar Pradesh. Bateshwar Fair was organised in the month of November every year and is considered the biggest fair in Uttar Pradesh. The Gangapur Cattle Fair was held in Gangapur in Rajasthan. Gangapur is situated on Bhilwara-Udaipur Road and named after the temple of Goddess Ganga.

\section{Structural base of livestock markets}

Brokers are professionally performing the function of price negotiation and settle price tactfully in cattle markets (Ubale and Lokhande, 2012). Each animal brought to the market is registered against a fee which varies across the market (Singh et al., 2014). The major share of animal value is bagged by the middlemen and the farmers depend on middlemen due to factors such as lack of knowledge in marketing, unscientific price fixation, absence of regulated markets and forced selling of animals (Kumar et al., 2019). Urgent need of money is another important reason for selling their livestock like education of the children, illness of family members, loan repayments and day to day activities (Bhattacharya et al., 2017).

The distribution of cattle market centres in the Solapur district of Maharashtra state has been largely influenced by physiographical units and locations. Markets near to the town are having high demand and transportation facilities favour the sellers and buyers. The weekly cattle market and fair cattle markets in India are mainly focused in the plain region which is fertile (Ubale and Lokhande, 2011). According to Khan
(2009), the temporal separation and locational spacing of cattle market centres in the Amravati district of Maharashtra are showing a particular pattern of spatial interactions between the buyers and sellers.

\section{Marketing strategies in livestock markets}

The price values of dairy animals show variation between the species (cattle and buffaloes), age (number of calving), presence of calf, sex of the calf, milk yield and health status of the animals (Kumar et al., 2019). However, the price of the dairy animal tends to increase up to three calvings and thereafter decreases. Among the cattle breeds, crossbred Holstein Friesians are having higher price value followed by crossbred Jersey and non-descript cattle which might be due to higher milk yield. Likewise, the Murrah breed ranked first among dairy buffaloes (Kumar et al., 2019; Jadoun et al., 2014). The value of pregnant heifer is found to be double when compared to non-pregnant heifers.

The home tract of world buffaloes is in the Indian subcontinent and it has the potential to boost the meat industry in India (Abdolghafour and Saghir, 2014). The selection and culling practices in Murrah buffaloes are performed by all owners and sort out the uneconomic and unproductive stock (Jadoun et al., 2014). However, they try to retain good quality buffaloes and sell the unproductive or low yielding animals in Haryana. The price estimation of small ruminant animals is mainly based on the body condition of the animal, followed by market demand (Ramesh et al., 2012). Buyers are ready to pay a higher price for a bullock which has a better general appearance like strong jaws, tight shoulder, strong feet, high body capacity, broad forehead and other characteristics like good temperament (Mueller et al., 2002).

\section{Constraints in livestock markets}

Livestock markets in India face serious lacunae in structural and functional aspects. Cattle fairs and markets are organized without any permanent infrastructural facilities like animal shelters and drinking water arrangements (Das et al., 2016). And also people had to spend time at night selling and buying animals under the open sky without adequate light and 
protection. Animals are often found to be in underfed condition due to the shortage of feeds and fodder and its higher prices. As a result, it also affects the pricing value of the animal and marketing efficiency (Das et al., 2014). The high cost of transportation of animals leads to an increase in the remunerative price and an important constraint for both sellers and buyers in the Eastern dry zone of Karnataka (Savanur et al., 2018). Lack of information regarding the pricing pattern of animals in the market is another important constraint and resulting in the wide range of variation in sale prices of the same breed in the same market (Singh et al., 2014; Das et al., 2016). The high entry and exit fee for animals is the major constraint followed by the dominance of intermediaries and unorganized pricing mechanism faced by the livestock traders and farmers in the southern districts of Tamil Nadu (Murugan et al., 2016). There is a chance of money and animals getting stolen especially during night due to less security compared with day time. In addition to this, the sellers from other states are facing harassment from local police at checkpoints and often asked for bribes for giving passes for animals (Das et al., 2016). All the cattle markets in Uttar Pradesh have no veterinary services like vaccination, onsite treatment and the issue of health certificate (Singh et al., 2014).

The cattle fair is at the risk of spreading infections due to lack of hygiene and sanitation during the rainy season because of waterlogging and mud (Das et al., 2016). Animals are predisposed to bovine respiratory disease due to long distance transportation (Van Engen and Coetzee, 2018). Uncontrolled transportation of animals leading to the spread of transboundary animal diseases like foot and mouth disease and also increase the chance of re-emergence (Subramaniam et al., 2013).

Long-distance transportation of animals between markets, increases stress and injuries due to the result of overloading and unfair management practices like inadequate padding support, improper handling and pointed objects in the vehicle (Alam et al., 2018). Several malpractices are adopted by the sellers to hide the physical defects with an animal such as rasping the teeth and file the rings around the horns, to hide the age (Kumar et al., 2019). Oil massaging throughout the body of the animal, incomplete milking, and udder massaging to increase the appearance of the animal. And also feeding of different herbs increase thirst as results high water intake leads to a well-fed condition (Das et al., 2016).

\section{Livestock markets in the context of COVID-19}

The COVID-19 pandemic creates worldwide pressure and a huge tension on the world economy and resulting in a recession stage. The disruption of the supply chain of food is occurring at both the national and international level due to the lockdown. The Ministry of Health and Family Welfare, Government of India and Indian Council of Medical Research (ICMR) have formulated guidelines, advisories for social distancing protocol, diagnosis, management, do's and don'ts and other reliable materials. Livestock markets are fully closed in the novel corona virus pandemic period. The COVID-19 pandemic has a worse impact on food security depends on the availability of food items and adversely affects the crop production, food and animal production sectors (Seleiman et al., 2020). This situation is badly affecting the rural people's income. In order to tackle the situations, farmers are looking for new opportunities to replace conventional livestock marketing. Online marketing of livestock arises during the COVID-19 period. Different e-commerce sites and social media platforms are filled with advertisements for animal trade. Ecommerce sites such as Indiamart, Karshika and Trade India have posts relating to the sale of cattle, poultry, goats and pets. Numerous Facebook pages and WhatsApp groups dealing exclusively with the sales of animals. These social media serve as a meeting place for people who are fully or partially involving in the animal husbandry sector. The online mode of financial transactions is also favouring the online marketing of animals.

Livestock markets have tremendous opportunity in the future. The scientifically orientated markets will help the farmers for improving their farm level production and increasing the marketing of livestock products. The innovation of new ideas will favour livestock markets especially for conducting animal fairs with the involvement of technologies. The incorporation of social media platform is resulting in a huge impact on the marketing of livestock. It is optimistic to believe that livestock markets will revive and flourish again in the post COVID-19 period, along with the support of online virtual platforms. 


\section{Conclusion}

Livestock markets have a significant role in the transaction of animals. Although India has a long tradition of animal fairs, present livestock markets are highly fragmented and unorganized. There are shortfalls in the structure and functioning of markets such as lack of infrastructures, unavailability of feed and fodder, transportation cost and unscientific and exploiting pricing practices. Unhygienic conditions and uncontrolled movement of animals across the borders increase the possibility of disease transmission. In the present context of COVID-19, cattle markets across the country are either closed or functioning with minimum activities. The future livestock markets should consider scientific and healthy practices, the welfare of animals and above all, the benefit of livestock farmers. The possibilities of online livestock markets will be beneficial for farmers, especially in the post COVID-19 era.

\section{Authorship contribution statement}

Vishnu Dev R. S. : Conceptualization, Writing original draft, Writing - review \& editing, Harik umar S.: Writing - review \& editing.

\section{Acknowledgments}

Authors acknowledge and thank to Kerala Veterinary and Animal Sciences University.

\section{Funding}

This compilation is a review article written by its authors and required no substantial funding to be stated.

\section{Declaration of Competing Interest}

All authors declare that there exist no commercial or financial relationships that could, in any way, lead to a potential conflict of interest.

\section{References}

Abdolghafour, B. and Saghir, A. 2014. Buffalo: a potential animal for quality meat production-a review. Livest. Res. Int. 2:19-29.

Alam, M., Hasanuzzaman, M., Hassan, M.M., Rakib, T.M., Hossain, M.E., Rashid, M.H., Sayeed, M.A., Philips, L.B. and Hoque,
M.A. 2018. Assessment of transport stress on cattle travelling a long distance $(\approx 648 \mathrm{~km})$, from Jessore (Indian border) to Chittagong, Bangladesh. Vet. Rec. open. 5:1-10.

Bharti, S.K., Pathak, V., Anita, and Singh, V.P. 2015. An overview of Indian Meat Marketing: Challenges and Scope. Indian J. Agric. Bus. 1:51-54.

Bhattacharjee, J. 2013. India-Bangladesh border management:The challenge of cattle smuggling. ORF Special Report No. 1, Observer Research Foundation, 20, Rouse Avenue, New Delhi. 8p.

Bhattacharjya, R., Saharia, J., Roychoudhury, R., Haque, A., Borah, M.C., Ray, M.N. and Hazarika, M. 2017. Livestock marketing in Assam-purpose and effect of seasonal variation. J. Ent. Zool. Stud. 5:1304-1307.

Das, G., Jain, D.K. and Pandit, A. 2014. Performance of Organised Animal Fairs of Rajasthan. Indian J. Agric. Econ. 69:290-299.

Das, G., Jain, D.K. and Pandit, A. 2016. Prioritization of constraints faced by different marketing functionaries in the organised cattle fairs of Rajasthan. Asian J. Dairy Food Res. 35:33-36.

Das, S.K. and Tripathi, H. 2013. Marketing of Livestock and Livestock Products in Sundarban Islands of India: Participatory Rural Appraisal. Int. J. Bioresource Stress Mgmt. 4:444-448.

Jadoun, Y.S., Jha, S.K., Bhadauria, P. and Kale, R. 2014. Marketing pattern of Murrah buffaloes among dairy farmers affected by Integrated Murrah Development Scheme of Haryana. Indian J. Dairy Sci. 67:541-546.

Khan, A. 2009. The Spatioi-Temporal Spacing of Cattle Market Places in Amravati District Maharashtra. Shodh, SamikshaaurMulyankan. 2:855-856.

Khan, F. 2017. Indian Fairs: A Significant Tool of Traditional Media and Its Impact on Social Development; With Special Reference to PushkarMela, Ajmer, India. Ascent Int. J. Res. Anal. 2:1-5.

Kumar, N.S., Nisha, P.R., Kumar, S.S. and Kumar, G.S. 2019. Pattern of Pricing of Dairy Cattle and Buffaloes in Tamil Nadu, India. Asian $J$. Agric. Ext. Econ. Sociology. 29:1-10.

Kumar, S., Kareemulla, K. and Rao, C.R. 2010. Goat marketing system in Rajasthan. Indian J. Agric. Mkt. 20:150-167.

Meena, G.L., Meena, K.K. and Jangid, M.K. 2017. Marketing of Milk Products and Transactions of Animals in Rajasthan. Int. J. Livestock Res. 


\section{$7: 190-200$}

Mueller, R.A., Prescott, E.S. and Sumner, D.A. 2002. Hired hooves: Transactions in a south Indian village factor market. Aust. J. Agric. Resour. Econ. 46:233-255.

Munjal, S. and Jauhari, V. 2015. Leveraging the cultural and economic value of fairs and festivals in India. Worldwide Hospitality and Tourism Themes. 7:417-423.

Murugan, M., Vasanthakumar, S. and Edwin, S.C. 2016. Constraint Analysis of Livestock Markets in Southern Districts of Tamil Nadu. Indian Vet. J. 9:14- 16.

Nomani, A. and Salman, M. 2016. Impact of beef ban on economy and meat processing industry of India: A complete value chain analysis. Mgmt. Stud. Econ. Syst. 2:325-334.

Ramesh, D., Meena, H.R. and Meena, K.L. 2012. Analysis of Small ruminant market system in different agro-climatic zones of Southern India. Vet. World. 5:288-293.

Savanur, M., Satyanarayan, K., Jagadeeswary, V. and Shilpa Shree, J. 2018. Constraints in Marketing of Cattle in Eastern Dry Zone of Karnataka. Int. J. Pure Appl. Biosci. 6:1018-1021.

Seleiman, M.F., Selim, S., Alhammad, B.A., Alharbi, B.M. and Juliatti, F.C. 2020. Will novel coronavirus (Covid-19) pandemic impact agriculture, food security and animal sectors?. Biosci. J. 36:1315-1326.

Senthilkumar, S., Ramprabhu, R. and Pandian, A. 2012. Small ruminant marketing practices in southern Tamil Nadu: A case study. Indian J. Small Rum. 18:129-131.
Singh, M. 2016. Pushkar and pushkar fair: its historical, religious and cultural perspective. Int. J. Arts Sci. 9:215-228.

Singh, R., Nath, T., Singh, P.K. and Kumar, K. 2014. Livestock Markets and Buyers' Perspectives on Voluntary versus Mandatory Disclosure of Information: Evidence from Cattle Markets in Uttar Pradesh. Indian. J. Agric. Econ. 69:271279.

Subramaniam, S., Pattnaik, B., Sanyal,A., Mohapatra, J.K., Pawar, S.S., Sharma, G.K., Das, B. and Dash, B.B. 2013. Status of Foot and mouth Disease in India. Transbound. Emerg. Dis. 60: 197-203.

Ubale, P.P. and Lokhande, T.N. 2011. Spatial distribution of cattle market centres in Solapur district of Maharashtra. Rev. Res. 1:39-43.

Ubale, P.P. and Lokhande, T.N. 2012. The Buffalo Marketing System in Solapur Cattle Market Centre of Solapur District: A Geographical Study. Asian Rev. Social Sci. 1:63-74.

Van Engen, N.K. and Coetzee, J.F. 2018. Effects of transportation on cattle health and production: a review. Anim. Hlth. Res. Rev. 19:142-154.

Varma, S., Ashraf, N.V.K. and S. R. Sujata. 2010. Captive Elephants in Bihar: An Investigation into the Population Status, Management and Welfare Significance. Elephants in Captivity: CUPA/ANCFTechnical Report. 14. Compassion Unlimited Plus Action (CUPA) Asian Nature Conservation Foundation (ANCF), Bangalore, and Wildlife Trust of India. 58p. 